\title{
RESEPSI PELAJAR TERHADAP TEKS KOMSAS JENDELA MENGHADAP JALAN
}

\author{
Students Reception towards "Jendela Menghadap Jalan” Novel as a Literature Component \\ in Bahasa Malaysia Subject
}

Nurhamizah Hashim

aaee@um.edu.my

NurYuhanis Mohd Nasir

yuhanis83@um.edu.my

Hashim Ismail

shim@um.edu.my

Eizah Mat Hussain

eizah@um.edu.my

Nurul Syahidah Tahir

nurulsyahidahtahir22@gmail.com

Akademi Pengajian Melayu, Universiti Malaya

\begin{abstract}
ABSTRAK
Kertas kerja ini membincangkan sebuah novel remaja berjudul Jendela Menghadap Jalan (Edisi Murid 2014) sebagai bahan kajian bagi menilai kesesuaian sesebuah teks yang dipilih untuk dijadikan teks KOMSAS (Komponen Sastera Dalam Mata Pelajaran Bahasa Malaysia). Novel Jendela Menghadap Jalan karya Ruhaini Mat Darin adalah terbitan Kumpulan Utusan Sdn. Bhd. yang pernah memenangi tempat kedua Hadiah Sastera Kumpulan Utusan (HSKU) tahun 2008. Novel ini kemudiannya telah terpilih menjadi teks KOMSAS bagi tingkatan 4 Zon 1 (Negeri Perlis, Kedah, Pulau Pinang dan Perak). Kajian dijalankan berdasarkan premis bahawa terdapat teks KOMSAS yang mencetuskan kontroversi kerana kandungannya didapati tidak sesuai sebagai bahan bacaan pelajar sekolah. Sebilangan teks KOMSAS yang dipilih dianggap tidak memaparkan unsur moral yang baik. Justeru itu, kajian ini bertujuan untuk mengenal pasti kesesuaian novel Jendela Menghadap Jalan diangkat sebagai teks KOMSAS. Kajian ini melibatkan seramai 151 orang responden yang terdiri daripada pelajar dan guru sekolah menengah. Data dikumpulkan daripada soal selidik dan dianalisis menggunakan perisian Statistical Package for Social Science (SPSS). Hasil kajian mendapati bahawa karya Ruhaini Mat Darin ini diterima dengan baik dalam kalangan pelajar dan guru-guru di empat buah sekolah yang dikaji. Malah isi kandungannya juga memenuhi ciri-ciri sebuah novel yang layak diangkat sebagai teks KOMSAS.
\end{abstract}

Kata kunci: Novel remaja, Jendela Menghadap Jalan, teks KOMSAS, Hadiah Sastera Kumpulan Utusan

\begin{abstract}
This paper discusses the suitability of “Jendela Menghadap Jalan”, a young adult novel as a literature component for Bahasa Malaysia subject or KOMSAS at schools. The novel written by Ruhaini Mat Darin was published by Kumpulan Utusan Sdn. Bhd. and had won second prize in Hadiah Sastera (Literary Prizes) Kumpulan Utusan (HSKU) in 2008. It was then chosen as a KOMSAS text for secondary four students in Zone 1 (comprises of Perlis, Kedah, Penang and Perak). The research is conducted based on the premise that there are some controversial
\end{abstract}


KOMSAS texts that seen as inappropriate reading materials for secondary school students. Some KOMSAS texts were thought to have unethical elements in the storyline. The purpose of this research is to identify whether Jendela Menghadap Jalan is a suitable novel as a KOMSAS text. A survey was conducted involving 151 secondary school students followed by an interview for teachers from four different schools in Zone 1. Data collected from the survey was analyzed using SPSS. The findings of this research show that the novel by Ruhaini Mat Darin is positively accepted as a KOMSAS text by students and teachers. The novel has good criteria to be chosen as a KOMSAS text.

Keywords: Young adult novel, Jendela Menghadap Jalan, KOMSAS text, Hadiah Sastera Kumpulan Utusan

\section{PENGENALAN}

Komponen sastera dalam sukatan mata pelajaran Bahasa Malaysia (BM) telah dilaksanakan sejak tahun 1984. Ketika itu, unsur sastera menjadi satu elemen yang penting dalam sukatan mata pelajaran BM. Meskipun, unsur sastera diselitkan dalam mata pelajaran BM, mata pelajaran sastera telah diajarkan secara formal dalam bentuk pengajaran dan pembelajaran. Hal ini sudah memadai untuk membuktikan kepentingan sastera itu sendiri untuk diajarkan kepada pelajar bagi mencapai matlamatnya, iaitu membina insan yang positif terhadap ilmu dalam kehidupan. Bagaimanapun, terdapat gesaan yang mencadangkan agar komponen sastera ini menjadi satu komponen yang wajib.

Jika dahulu, komponen sastera diajarkan dalam sukatan BM, namun ia tidak termasuk dalam mana-mana peperiksaan awam seperti Penilaian Menengah Rendah (PMR) atau Sijil Pelajaran Malaysia (SPM). Teks sastera yang diajarkan juga tertakluk kepada pihak sekolah untuk memilih bahan tersebut. Malah, proses pengajaran dan pembelajaran juga tidak melibatkan semua pelajar kerana ia bukanlah mata pelajaran yang wajib. Oleh yang demikian, keberkesanan unsur sastera dalam sukatan mata pelajaran BM menjadi satu pertikaian. Jika situasi sedemikian berterusan, maka sukar untuk melihat kesan penyerapan unsur sastera itu sendiri. Rentetan daripada itu, gesaan daripada Mesyuarat Jemaah Menteri Bil.4/99 bertarikh 24 Februari 1999 untuk memasukkan komponen sastera dalam sukatan mata pelajaran BM tingkatan satu hingga tingkatan lima telah diterima baik oleh Pusat Perkembangan Kurikulum. Hasilnya, cadangan supaya Kesusasteraan Melayu diperkenalkan sebagai satu komponen wajib dalam mata pelajaran BM telah diluluskan dalam mesyuarat jawatankuasa Kurikulum Pusat Bil.2/99 pada 11 Jun 1999 (Ariff Mohamad, 2009:3).

Pada awal pelaksanaannya, KOMSAS telah diperkenalkan secara berperingkat bermula dengan tingkatan satu dan tingkatan empat pada Mac 2000, tahun 2001 untuk tingkatan dua dan lima dan tingkatan tiga bermula pada tahun 2002. Dari segi pelaksanaannya dalam kelas, Kementerian Pendidikan Malaysia telah memperuntukkan sebanyak 56 waktu dalam tempoh 26 minggu setahun mulai Mac 2000. Hal ini amat bertepatan dengan konsep "4+2" yang membawa maksud empat waktu pembelajaran bahasa dan baki dua waktu untuk pembelajaran KOMSAS.

Hal ini bermakna setiap pelajar akan membaca sebanyak 130 hasil karya sastera sepanjang tempoh persekolahan bermula daripada tingkatan satu hingga tingkatan lima. Justeru, pengenalan KOMSAS kepada pelajar sekolah membawa kepada percambahan kreativiti dalam kalangan pelajar di samping menggalakkan pelajar untuk lebih mendalami dan menghayati kebudayaan dan kesenian yang dimiliki oleh masyarakat. Hal ini amat bertepatan dengan objektif pengajaran dan pembelajaran KOMSAS dalam mata pelajaran BM yang hendak dicapai, iaitu:

i. Meningkatkan dan mengukuhkan minat membaca pelbagai genre sastera seperti novel, cerpen, drama, prosa tradisional, puisi moden, dan puisi tradisional.

ii. Mengenal dan menggunakan istilah sastera, iaitu tema dan persoalan, watak dan perwatakan, gaya bahasa, latar, plot, sudut pandangan, nilai murni dan pengajaran.

iii. Mengenal, menghayati dan menghargai karya sastera bagi mengukuhkan kemahiran bertutur, membaca dan menulis.

iv. Mengenal pengarang berdasarkan karya yang telah diperakui seperti pengarang Sasterawan Negara.

v. Mendapat nilai murni dan pengajaran daripada karya sastera yang dibaca. 
vi. Menghasilkan karya sastera yang kreatif seperti dapat melahirkan novel, cerpen dan drama yang bermutu tinggi yang boleh dibanggakan.

(Pusat Perkembangan Kurikulum, Kementerian Pendidikan Malaysia: 2001)

Secara keseluruhannya, dapat dikatakan bahawa objektif yang hendak dicapai ternyata menjurus kepada perkembangan berbahasa yang boleh digarap oleh pelajar di samping nilai-nilai murni yang dipupuk dalam kalangan diri individu. Hal ini bermakna bukan sahaja menjana kepada kecerdasan minda individu pelajar itu malah kemuliaan budi pekerti juga dapat dirangsang dan disemai sejajar dengan tujuan kebudayaan kebangsaan.

Namun begitu, tujuan pelaksanaan KOMSAS dalam mata pelajaran BM bukan sekadar ingin memenuhi objektif yang telah ditetapkan. Perkara yang lebih utama ialah KOMSAS itu mempunyai kepentingannya yang tersendiri. Jika dilihat secara umum, melalui pelaksanaan KOMSAS dalam mata pelajaran BM, pelajar bukan sahaja dapat meningkatkan kemahiran berbahasa malah pelajar turut dapat mengekspresikan pengalaman atau emosi sendiri melalui penciptaan karya- karya sastera. Lanjutan itu, lahir bentuk pemikiran pelajar yang bersifat kreatif dan kritis hasil daripada imaginasi dan kreativiti yang digarapkan melalui pembacaan teks KOMSAS.

Secara tidak langsung, pelaksanaan KOMSAS ini telah membuka satu ruang baru kepada pelajar yang merupakan generasi masa depan dengan mendedahkan mereka untuk berfikir di luar kotak dan tidak sekadar mengharapkan input daripada guru semata-mata. Kemahiran berfikir secara kritis mendorong kepada kerasionalan diri individu dalam membuat sesuatu keputusan. Pemikiran yang lahir daripada imaginasi dan pengamatan terhadap karya sastera mendorong kepada kecerdasan minda pelajar dalam menginterpretasikan setiap tingkah laku.

Sehubungan dengan itu, jelaslah bahawa sesebuah karya yang dipilih untuk menjadi teks KOMSAS mempunyai peranan yang penting. Teks KOMSAS yang menjadi bahan bacaan umum para pelajar menjadi satu elemen yang dominan dalam mempengaruhi pemikiran pelajar. Oleh itu, karya sastera yang benar-benar berkualiti dipilih sebagai teks KOMSAS dalam memberi sumbangan kepada pembinaan modal insan terbilang. Lanjutan daripada itu, Pusat Perkembangan Kurikulum bertindak sebagai institusi yang bertanggungjawab dalam memilih karya-karya yang sesuai untuk dijadikan teks bacaan bagi pelajar tingkatan satu hingga pelajar tingkatan lima. Senarai karya yang sesuai dijadikan teks KOMSAS akan dikemukakan dan perlu mendapat persetujuan dalam Mesyuarat Jawatankuasa Kurikulum Pusat sebelum menjadi teks KOMSAS secara rasmi. Pemilihan sesebuah teks diteliti sama ada teks tersebut mampu memenuhi aspek-aspek yang bersesuaian dalam mencapai matlamat pengajaran dan pembelajaran KOMSAS tanpa menjejaskan matlamat asal pengajaran bahasa.

Lazimnya, kebanyakan teks KOMSAS yang dipilih terdiri daripada teks-teks yang pernah memenangi pelbagai anugerah buku seperti anugerah Hadiah Sastera Perdana Malaysia mahupun anugerah Hadiah Sastera Kumpulan Utusan (HSKU). HSKU merupakan sebuah sayembara sastera yang dianjurkan oleh syarikat penerbitan Kumpulan Utusan yang berlangsung di Malaysia sejak tahun 1985 lagi. Penekanan khusus diberikan kepada karya kreatif yang diterbitkan dalam ruangan sastera pelbagai terbitan Kumpulan Utusan, majalah, dan akhbar mingguan. Setiap penyertaan dibahagikan mengikut kategori genre sesebuah karya itu sendiri seperti rencana sastera, kajian sastera, kategori puisi, cerpen remaja dan juga kajian novel remaja. HSKU berkonsepkan kepada pemberian hadiah kepada karya yang mencapai tahap mutu kreatif yang membanggakan yang dinilai oleh ahli-ahli panel. Lantaran itu, beberapa novel yang memenangi anugerah HSKU ini dipilih sebagai teks KOMSAS bagi bahan bacaan di sekolah.

Jika tidak memenangi anugerah buku sekalipun, kebanyakan daripada teks KOMSAS diterbitkan oleh syarikat penerbitan yang sudah kukuh dan dipercayai dari segi kawalan kualitinya. Oleh yang demikian, jelas bahawa teks KOMSAS yang sedia ada merupakan teks yang dianggap memenuhi ciri-ciri novel remaja yang sesuai untuk dijadikan bahan bacaan bagi peringkat sekolah. Justeru, kajian ini merupakan satu inisiatif yang diambil untuk melihat kepada novel remaja yang pernah memenangi anugerah Hadiah Sastera Kumpulan Utusan dan pada masa yang sama telah dipilih menjadi teks KOMSAS. 
Kajian ini memberikan fokus kepada teks KOMSAS tingkatan empat, iaitu Jendela Menghadap Jalan yang mewakili Zon 1 bagi negeri Perlis, Kedah, Pulau Pinang dan Perak. Teks KOMSAS Jendela Menghadap Jalan ini merupakan hasil tulisan Ruhaini Matdarin yang pernah memenangi anugerah tempat kedua bagi Hadiah Sastera Kumpulan Utusan (HSKU) pada tahun 2008. Jendela Mengadap Jalan dipilih menjadi teks KOMSAS bermula pada tahun 2015 sehingga tahun 2019. Objektif kajian ini adalah untuk mengenal pasti kesesuaian novel Jendela Menghadap Jalan diangkat sebagai teks KOMSAS. Kajian ini telah dijalankan di Perak untuk mendapatkan data berkaitan resepsi dalam kalangan pembaca yang terdiri daripada para pelajar. Seramai 151 orang pelajar yang terdiri daripada pelajar sekolah menengah tingkatan lima yang bersekolah di sekitar daerah Perak Tengah, iaitu Sekolah Menengah Sultan Abdul Jalil, Sekolah Menengah Kebangsaan Maharaja Lela, MRSM Pasir Salak dan Sekolah Menengah Agama Raja Nazrin Shah telah terlibat secara langsung untuk menjawab borang soal selidik yang diedarkan. Selain soal selidik, temu bual dan pemerhatian terhadap para pelajar dan guru turut dijalankan.

\section{KAJIAN LEPAS}

Beberapa sarjana dan para pengkaji telah melakukan kajian berkaitan teks KOMSAS. Antara kajian yang telah dilakukan adalah kajian oleh Ariff bin Mohamad bertajuk "Analisis Kesesuaian Pemilihan Teks Bagi Genre Cerpen Dan Novel Komponen Sastera Dalam Pendidikan Bahasa Melayu" dari Universiti Pendidikan Sultan Idris pada tahun 2009. Kajian beliau berkaitan dengan kesesuaian pemilihan teks cerpen dan novel KOMSAS dalam pengajaran BM yang seterusnya menyenaraikan ciriciri pemilihan teks yang sesuai digunakan sebagai bahan pengajaran. Kajian ini melibatkan seramai 55 orang responden yang bertempat di tujuh buah sekolah sekitar daerah Kuantan, Pahang.

Dapatan kajian beliau mendapati bahawa majoriti pelajar mempunyai minat dan persepsi yang positif terhadap pemilihan teks cerpen dan novel KOMSAS dalam pengajaran BM. Malah, pelajar turut menyetujui pelaksanaan KOMSAS dalam pengajaran BM. Bukan itu sahaja, pelajar juga menyetujui pengajaran guru dan penggunaan bahan bantu mengajar bagi membantu pelajar dalam pembelajaran KOMSAS. Manakala dari segi pemilihan teks, pelajar lebih cenderung ke arah ciri-ciri teks yang mudah, menarik, bermutu, mengandungi nilai murni dan popular. Kajian yang telah dilakukan oleh Ariff Bin Mohammad ini adalah untuk melihat kesesuaian pemilihan teks cerpen dan novel KOMSAS dalam pengajaran Bahasa Melayu seterusnya menyenaraikan ciri-ciri pemilihan teks tersebut yang sesuai digunakan sebagai bahan pengajaran. Manakala kajian ini pula hanya akan memfokuskan satu teks KOMSAS sahaja iaitu, teks Jendela Menghadap Jalan karya Ruhaini Mat Darin Novel telah terpilih menjadi teks KOMSAS bagi tingkatan 4 Zon 1 (Negeri Perlis, Kedah, Pulau Pinang dan Perak).

Seterusnya kajian yang telah dilakukan oleh Faziela Abu Bakar @ Che Din dan Nik Rafidah Nik Muhammad Affendi daripada Fakulti Bahasa Moden dan Komunikasi, Universiti Putra Malaysia pada tahun 2015. Kajian yang telah dilakukan bertajuk "Unsur Emosi dalam Novel KOMSAS". Kajian ini bertujuan untuk mengenal pasti dan menganalisis unsur emosi yang diungkapkan oleh pengarang dalam setiap karya yang dihasilkan. Malah, kajian ini juga melihat unsur-unsur emosi yang berlaku dalam kehidupan remaja dengan menggunakan pendekatan psikologi. Justeru, hasil kajian mendapati novel-novel mempunyai pelbagai jenis emosi sama ada emosi positif mahupun negatif. Hal ini kerana, jika dilihat konteks kehidupan itu sendiri, manusia sememangnya tidak dapat dipisahkan dengan masalah hidup, begitu juga dengan permasalahan yang timbul dalam kalangan remaja. Kajian Yang telah dilakukan oleh oleh Faziela Abu Bakar @ Che Din dan Nik Rafidah Nik Muhammad Affendi ini lebih memfokuskan unsur emosi yang terdapat dalam teks KOMSAS. Manakala kajian ini pula hanya melihat penerimaan pelajar terhadap teks KOMSAS Jendela Menghadap Jalan. 


\section{MINAT TERHADAP NOVEL KOMSAS SECARA UMUM}

Pemilihan sesebuah teks KOMSAS memperlihatkan proses bagi sesebuah novel remaja dipilih berdasarkan kriteria yang memenuhi tiga dimensi utama yang diberikan penekanan dalam menentukan sesebuah teks KOMSAS. Dimensi yang dimaksudkan terdiri daripada dimensi bahan yang merujuk kepada teks yang dipilih itu hendaklah berkualiti, terbaik, sesuai dan menepati kurikulum kebangsaan. Hal ini kerana teks KOMSAS melibatkan pembaca yang terdiri daripada para pelajar sekolah. Kualiti sesebuah teks itu diberikan penekanan kerana teks tersebut akan mempengaruhi pemikiran pelajar. Sesebuah teks yang tidak berkualiti akan mempengaruhi pemikiran pelajar dengan pemikiran yang negatif dan perkara ini akan menyumbang kepada kesan yang tidak baik kepada generasi kini.

Seterusnya, dimensi guru. Sesebuah teks yang dipilih haruslah mampu dilaksanakan oleh guru dalam proses pengajaran dan pembelajaran. Hal ini bermakna, teks tersebut hendaklah sesuai dengan kepakaran guru dalam menyampaikan pengajaran kepada pelajar. Dalam konteks ini, sesebuah teks tersebut hendaklah menepati Falsafah Pendidikan Kebangsaan dan Rukun Negara. Secara keseluruhannya, Falsafah Pendidikan Kebangsaan merupakan usaha yang berterusan dalam melahirkan generasi yang berilmu, bertanggungjawab dan berkeupayaan dalam menyejahterakan serta memberi sumbangan terhadap keharmonian dan kemakmuran masyarakat dan negara. Usaha ini muncul daripada generasi yang mempunyai keperibadian yang seimbang dari segi jasmani, emosi, rohani mahupun inteleknya berdasarkan kepercayaan dan kepatuhan kepada Tuhan. Selari dengan Rukun Negara yang menetapkan kepercayaan kepada Tuhan sebagai prinsip yang utama. Prinsip ini disusuli dengan kesetiaan kepada Raja, perlembagaan yang luhur, undang-undang yang menjadi teras kedaulatan serta amalan budi pekerti yang sopan dalam kalangan masyarakat. Justeru, sesebuah teks yang hendak diangkat menjadi teks komsas hendaklah mempunyai inti pati yang menjurus kepada nilai-nilai yang mampu menyuntik jiwa pelajar dalam memperkasakan perkembangan diri mereka dalam usaha ke arah negara yang berkemajuan.

Akhir sekali merupakan dimensi pelajar yang memberi perhatian kepada teks yang mudah untuk difahami oleh pelajar, dekat dengan kehidupan pelajar, boleh menarik minat pelajar, mencetuskan kreativiti pelajar dan seterusnya teks itu boleh dihayati oleh pelajar. Dimensi pelajar merupakan aspek yang amat penting kerana hal ini merupakan hasil yang boleh dilihat sama ada sesebuah teks KOMSAS itu membawa kepada kesan positif mahupun sebaliknya. Sesebuah teks yang mudah difahami dan mempunyai latar belakang yang dekat dengan kehidupan seharian pelajar mampu merangsang minat sekali gus meningkatkan kefahaman pelajar. Secara tidak langsung, perkara ini membantu dalam proses pengajaran dan pembelajaran. Justeru, hasrat untuk menyerapkan unsur sastera dalam sukatan pelajaran BM dapat dicapai. Walau bagaimanapun, jika sesebuah teks itu tidak memenuhi tanggapan pelajar maka hal ini akan memaksa guru untuk memainkan peranan dalam mengadakan proses pengajaran dan pembelajaran dengan sebaik mungkin supaya pelajar tetap dapat menguasai teks KOMSAS tersebut.

Proses pemilihan novel remaja sebagai teks KOMSAS bukan satu perkara yang mudah. Hal ini demikian kerana ia melibatkan proses pembelajaran dan pengajaran yang terdiri daripada guru dan pelajar. Pemilihan yang teliti dan telus amat penting dalam memastikan novel remaja yang dipilih sesuai untuk menjadi teks KOMSAS yang memenuhi kriteria-kriteria yang selari dengan sukatan mata pelajaran BM. Bukan itu sahaja, malah pemilihan novel remaja tersebut mestilah mempunyai kebolehan untuk menarik minat pelajar.

Carta 1 menunjukkan dapatan kajian bagi kekerapan pelajar yang berminat dengan novel KOMSAS. 


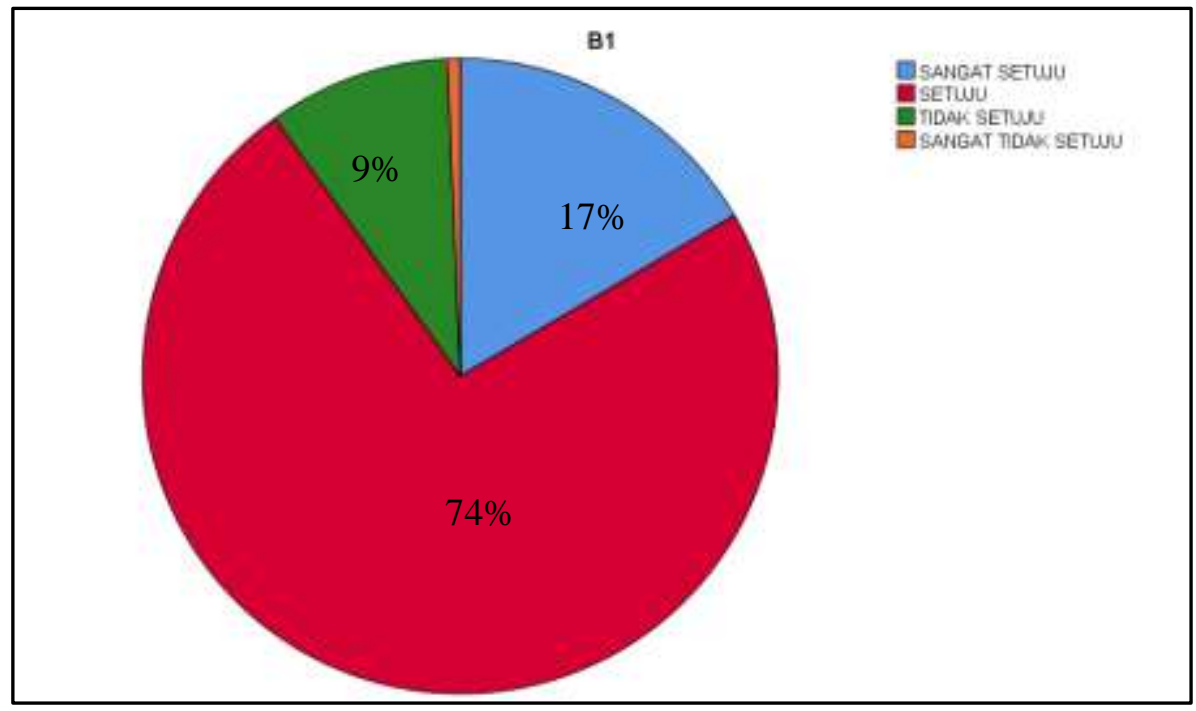

RAJAH 1 Peratusan tahap minat pelajar terhadap novel KOMSAS

Kajian ini menunjukkan seramai 111 orang daripada 151 orang pelajar berminat untuk membaca novel KOMSAS. Guru dan rakan sebaya merupakan individu yang memainkan peranan dalam mendorong peratusan sebanyak 73.5 pelajar berminat membaca novel KOMSAS. Hasil daripada temu bual, mendapati bahawa kebanyakan pelajar menyatakan mereka berminat untuk membaca novel KOMSAS kerana mendapat galakan dan rangsangan daripada guru ketika proses pengajaran dan pembelajaran diadakan. Malah, rakan sebaya turut memberikan dorongan dengan mengadakan pembacaan bersama-sama dan berkongsi bahan rujukan mengenai novel KOMSAS.

Selain itu, pelajar juga dapat mengisi masa lapang dengan membaca novel KOMSAS yang secara tidak langsung menimbulkan minat untuk membaca novel KOMSAS. Situasi yang berlaku adalah teks KOMSAS dibekalkan lebih awal sebelum sesi persekolahan bermula. Perkara ini telah mendorong pelajar membaca novel KOMSAS demi mengisi masa yang terluang meskipun sesi pembelajaran dan pengajaran belum bermula. Apabila memasuki sesi pembelajaran dan pengajaran, pelajar lebih mudah untuk memahami pengajaran guru. Lama-kelamaan, amalan tersebut menjadi minat dari tahun ke tahun. Hal ini kerana, perkara ini membawa kepada kesedaran pelajar itu sendiri untuk membaca novel lebih awal sebelum sesi pengajaran dan pembelajaran diadakan untuk memudahkan proses kefahaman. Hasil daripada kesedaran itu jugalah, minat membaca itu timbul.

Bertitik tolak daripada minat pelajar terhadap pembacaan novel KOMSAS, kajian ini telah melihat resepsi pelajar itu sendiri terhadap novel yang menjadi bahan bacaan mereka bagi Zon 1 iaitu negeri Perlis, Kedah, Pulau Pinang dan Perak. Novel yang dimaksudkan merupakan novel bagi teks pelajar tingkatan empat, iaitu Jendela Menghadap Jalan yang ditulis oleh Ruhaini Mat Darin. Resepsi para pelajar ditunjukkan dalam Carta 2. 


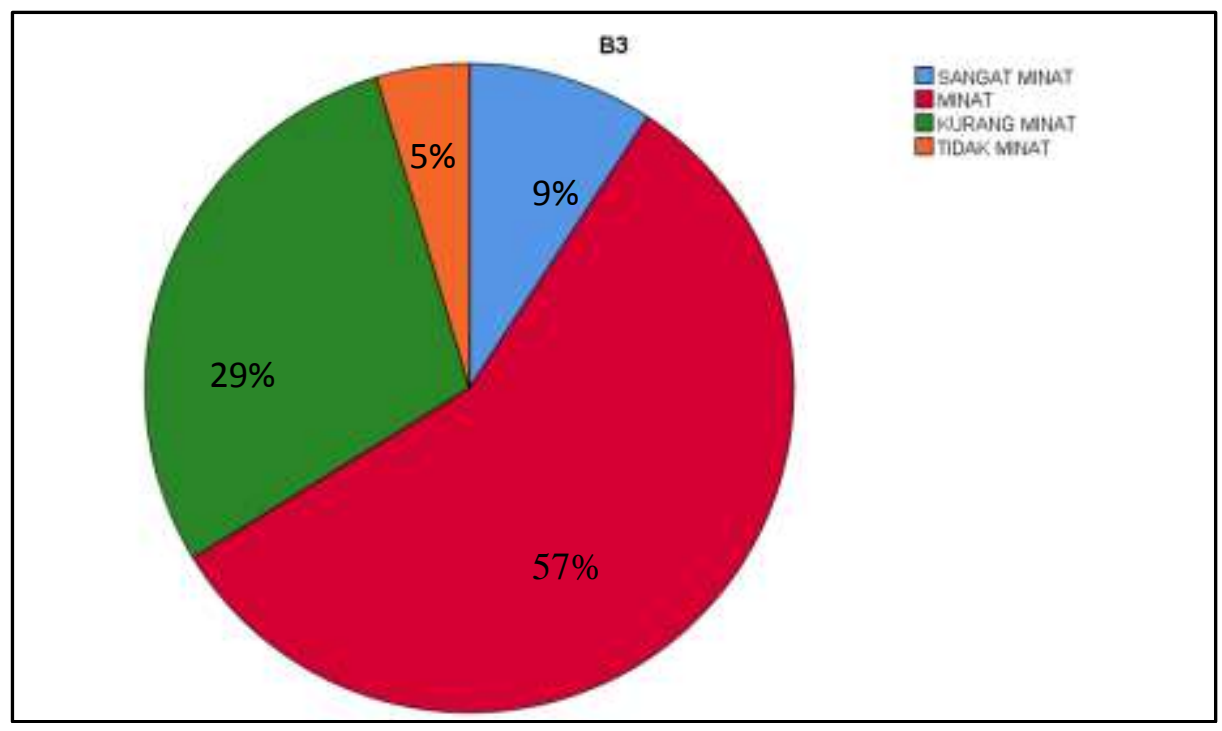

RAJAH 2 Pandangan pelajar terhadap Jendela Menghadap Jalan

Secara puratanya dapat dilihat bahawa seramai $57 \%$ pelajar menyatakan pandangan bahawa mereka berminat terhadap teks KOMSAS Jendela Menghadap Jalan. Peratusan ini membuktikan bahawa masih terdapat pelajar yang kurang berminat terhadap teks KOMSAS, iaitu sebanyak $29 \%$ dan disusuli dengan 5\% yang menyatakan tidak minat. Meskipun tidak mencapai separuh daripada 151 orang pelajar yang menyatakan kurang minat, namun jumlah ini dilihat agak tinggi dan menimbulkan persoalan tentang sebab yang mendorong sebahagian pelajar kurang berminat dan tidak berminat langsung terhadap teks tersebut. Justeru, perkara ini dapat dirumuskan melalui soalan menyatakan sebab mereka berpandangan sedemikian (rujuk Carta 3).

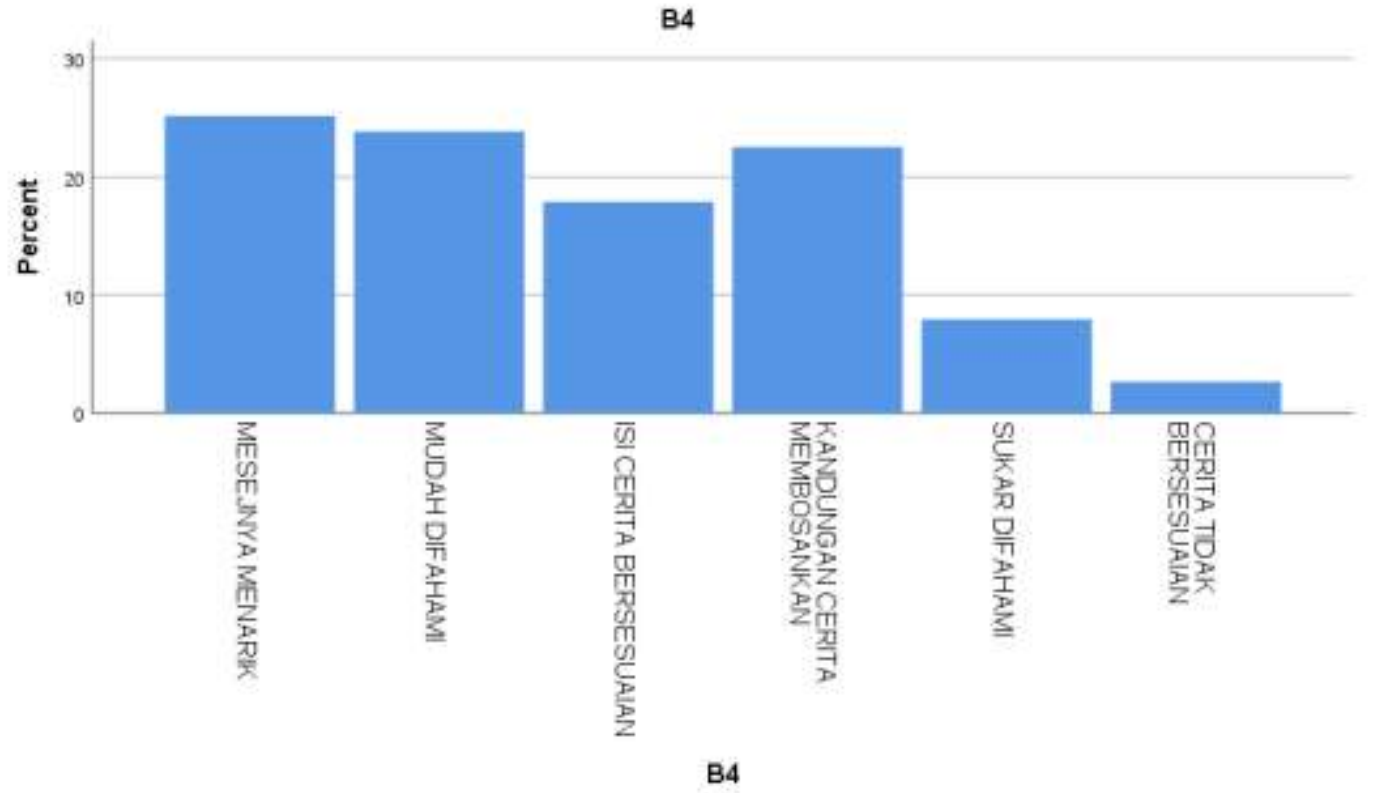

RAJAH 3 Faktor yang mempengaruhi resepsi terhadap Jendela Menghadap Jalan

Berdasarkan pemerhatian, antara sebab yang mendorong kepada bilangan pelajar yang kurang berminat dan tidak minat terhadap teks KOMSAS adalah disebabkan kandungan cerita yang 
membosankan dan teks KOMSAS yang sukar difahami yang mana masing-masing mewakili peratusan sebanyak $22 \%$ dan $8 \%$. Selebihnya adalah disebabkan pelajar yang menyatakan pandangan bahawa mereka minat terhadap teks tersebut kerana mesejnya yang menarik yang membawa kepada peratusan sebanyak 25\%. Justeru, peratusan ini dapat menyimpulkan bahawa teks KOMSAS ini kurang diminati kerana ciri-ciri kandungan teks itu sendiri yang tidak menarik minat para pelajar. Walau bagaimanapun, masih terdapat sebahagian pelajar yang minat terhadap teks KOMSAS dan memberikan pandangan bahawa teks tersebut mempunyai mesej yang menarik di samping mudah difahami dan mempunyai isi cerita yang bersesuaian. Di sini, dapat dilihat bahawa terdapat dua perbezaan pandangan daripada kumpulan pelajar yang minat dan sebaliknya. Besar kemungkinan hal ini disebabkan oleh penerimaan pelajar itu sendiri terhadap teks dan perspektif mereka sendiri dalam menanggapi bahan bacaan tersebut.

\section{KRITERIA PEMILIHAN NOVEL UNTUK TEKS KOMSAS}

Perkara yang sama terjadi apabila melihat kepada aspek kesesuaian kandungan novel. Borang soal selidik bahagian $\mathrm{C}$ lebih menjurus kepada soalan-soalan berbentuk pendapat pelajar terhadap situasi yang berlaku dalam teks KOMSAS tersebut. Bahagian ini menggalakkan pelajar untuk memberikan jawapan berdasarkan tindakan yang mereka akan lakukan jika berdepan dengan situasi yang sama tanpa terikat dengan jalan cerita novel tersebut. Tujuannya adalah untuk melihat kesesuaian kandungan novel ini sama ada bertepatan dengan tahap pemikiran para pelajar tingkatan 4 ataupun sebaliknya. Rata-rata para pelajar mempunyai pendapat mereka yang tersendiri. Hal ini memberikan petanda yang positif kerana melalui pendapat yang berbeza ini dapat dirumuskan bahawa para pelajar yang terdiri daripada minat membaca mahupun kurang minat membaca masih mampu memberikan pandangan berdasarkan akal fikiran mereka sendiri. Malah, perkara ini juga membawa maksud bahawa teks KOMSAS ini telah berjaya merangsang para pelajar untuk berfikir berdasarkan prinsip individu. Soalan sedemikian dapat dilihat seperti soalan tindakan yang para pelajar ambil jika berlaku keganasan rumah tangga dalam kalangan kenalan terdekat mereka. Lantaran itu, pendapat pelajar dapat dilihat seperti berikut (rujuk Jadual 1):

JADUAL 1 Tindakan Jika Berlaku Keganasan Rumah Tangga

\begin{tabular}{|l|c|c|}
\hline \multicolumn{1}{|c|}{ Tindakan } & Kekerapan & Peratus (\%) \\
\hline Melaporkan kepada pihak berkuasa & 77 & 51.0 \\
\hline Memberikan sokongan moral kepada mangsa & 65 & 43.0 \\
\hline Tidak mencampuri hal peribadi orang lain & 9 & 6.0 \\
\hline Menjauhi mereka & 0 & 0 \\
\hline JUMLAH & 151 & 100 \\
\hline
\end{tabular}

Jadual 1 jelas menunjukkan seramai 77 orang pelajar akan membuat keputusan untuk melaporkan kepada pihak berkuasa sekiranya keganasan rumah tangga sebagaimana yang dilakukan oleh watak utama, Lili. Manakala, 65 orang pelajar yang lain pula akan memberikan sokongan moral kepada mangsa seperti yang berlaku kepada watak Che Jah yang diceritakan sebagai isteri yang melalui detik-detik hitam bersama suaminya. Baki daripada jumlah pelajar pula, memilih untuk tidak mencampuri hal peribadi orang lain. Meskipun tindakan yang diambil adalah berbeza, namun perkara ini menjadi satu petunjuk bahawa setiap pelajar mempunyai pendirian yang tersendiri. Hal ini amat penting dalam melahirkan generasi muda yang bakal menerajui masa depan, negara memerlukan modal insan yang berpegang teguh terhadap prinsip hidupnya. Sifat ini penting bagi mengelakkan individu yang mudah beralih arah yang diibaratkan sebagai lalang dalam mempelopori sesuatu keputusan dalam 
sesebuah organisasi. Dalam soal ini, tiada yang betul dan tiada yang salah. Setiap tindakan ataupun respons yang dipilih oleh pelajar itu adalah didasari oleh pengalaman mereka sendiri yang digarap melalui pemerhatian mereka terhadap orang sekeliling mahupun isu semasa yang menular.

Secara tidak langsung, teks KOMSAS ini dilihat sebagai satu elemen yang mampu menyuntik nilai-nilai positif sekali gus memberikan motivasi terhadap pelajar. Tindakan mahupun sikap yang ditonjolkan oleh watak utama dibantu oleh watak-watak sampingan akan meningkatkan lagi motivasi dalam kalangan pelajar. Hal ini demikian kerana, teks yang baik mampu mempengaruhi pembaca untuk menghayati lantas mengamalkan nilai-nilai yang baik menerusi pembawakan watak yang disusun dan diceritakan dengan teratur. Kebarangkalian untuk watak dalam teks Jendela Menghadap Jalan mempunyai sifat yang sama dengan pembaca adalah jelas kerana faktor usia yang tidak jauh. Jadi, sedikit sebanyak nilai-nilai positif yang dimiliki oleh watak utama tersebut akan memberikan kesan ke dalam diri pelajar. Sebagaimana Lili gemar membaca buku dan mengamalkan pemakanan yang sihat, begitu jugalah yang akan dilakukan oleh pelajar. Segelintir pelajar pasti akan terkesan dengan amalan pemakanan yang kurang sihat yang diamalkan dan mula untuk mengikuti sikap Lili yang menjaga pemakanan. Hal ini dapat dilihat berdasarkan respon tidak oleh pelajar mengenai soalan mengamalkan pemakanan yang sihat seperti Lili (Rujuk Jadual 2).

JADUAL 2 Amalan Pemakanan yang Sihat

\begin{tabular}{|c|c|c|}
\hline Amalan pemakanan sihat & Kekerapan & Peratus $(\%)$ \\
\hline Ya & 58 & 38 \\
\hline Tidak & 6 & 4 \\
\hline Kadangkala & 87 & 58 \\
\hline JUMLAH & 151 & 100 \\
\hline
\end{tabular}

Jadual 2 menunjukkan jumlah majoriti sebanyak 87 orang adalah pelajar yang mengamalkan amalan pemakanan sihat secara tidak menentu iaitu kadang kala selebihnya adalah 58 orang yang memang mengamalkan dan baki adalah pelajar yang tidak mengamalkan amalan pemakanan sihat. Jumlah ini menunjukkan bahawa masih terdapat ramai pelajar yang tidak menitik beratkan penjagaan kesihatan masing-masing. Justeru, berdasarkan pembacaan pelajar terhadap teks KOMSAS telah membawa kesedaran kepada kepentingan untuk menjaga pemakanan seharian. Tanpa disedari, teks KOMSAS ini memberikan satu kesan yang positif dalam kalangan pelajar. Kelompok pelajar yang menjawab kadang kala bagi soalan tersebut sedikit sebanyak terkesan dengan cara watak Lili yang begitu menjaga pemakanan sehariannya. Ringkasnya, bentuk-bentuk soalan sedemikian kelihatan agak remeh, namun jika dilihat dari sudut yang berbeza soalan-soalan tersebut membuktikan bahawa teks KOMSAS Jendela Menghadap Jalan mempunyai nilai-nilai yang baik yang secara tidak langsung mampu memberikan motivasi dalam diri pelajar itu sendiri. Jika pelajar benar-benar menghayati dan memberikan pengamatan yang tinggi dalam pembacaan mereka, nescaya nilai-nilai positif dapat dipupuk sekaligus meningkatkan motivasi dalam diri pelajar.

Hal ini adalah rentetan daripada dasar kurikulum kebangsaan yang merujuk kurikulum kebangsaan sebagai suatu program pendidikan yang termasuk kurikulum dan kegiatan kokurikulum yang merangkumi semua pengetahuan, kemahiran, norma, nilai, unsur kebudayaan dan kepercayaan untuk membantu perkembangan seseorang murid dengan sepenuhnya dari segi jasmani, rohani, mental dan emosi serta untuk menanam dan mempertingkatkan nilai moral yang diingini dan untuk menyampaikan pengetahuan (Akta Pendidikan 1996). Perkara ini secara tidak langsung menjelaskan bahawa proses pembelajaran dan pengajaran merangkumi nilai-nilai kemanusiaan yang boleh dipupuk ke dalam diri pelajar melalui bahan-bahan bacaan seperti teks KOMSAS.

Proses pemilihan teks KOMSAS melibatkan penekanan diberikan kepada ciri-ciri sesebuah novel remaja sebelum layak diangkat menjadi teks bahan bacaan di peringkat sekolah. Antara ciri-ciri bagi sesebuah novel remaja itu tidak lain tidak bukan, aspek bahasa. Aspek bahasa memainkan peranan 
yang amat penting kerana bahasa bukan sahaja melambangkan bangsa tetapi juga menjadi cerminan kepada akhlak dan sahsiah seseorang. Lantas, bahasa memainkan peranan yang penting dalam sesebuah novel. Tambahan pula, novel remaja tersebut akan menjadi bahan bacaan para pelajar sekolah. Bahasa yang baik bukan sahaja mempengaruhi pelajar dari segi tutur kata dan penulisan, malah bahasa yang puitis akan dapat menarik minat membaca para pelajar. Perkara ini amat penting bagi menggalakkan minat pembacaan pelajar dalam usaha untuk memberi pendedahan mengenai sastera sekaligus menyemai nilai-nilai kebudayaan budaya bangsa dalam diri pelajar.

Justeru, aspek bahasa teks KOMSAS Jendela Menghadap Jalan menunjukkan teks ini mengandungi bahasa yang indah dan menarik seperti mana diperakui oleh para pelajar (rujuk Jadual 3).

JADUAL 3 Penggunaan Gaya Bahasa yang Menarik dalam Jendela Menghadap Jalan

\begin{tabular}{|l|c|c|}
\hline \multicolumn{1}{|c|}{ Pemeringkatan } & Kekerapan & Peratus (\%) \\
\hline Sangat Tidak Setuju & 4 & 3 \\
\hline Tidak Setuju & 26 & 17 \\
\hline Setuju & 85 & 56 \\
\hline Sangat Setuju & 36 & 24 \\
\hline \multicolumn{1}{|c|}{ JUMLAH } & 151 & 100 \\
\hline
\end{tabular}

Walaupun, seramai 85 orang pelajar yang bersetuju namun terdapat juga sebilangan pelajar yang tidak begitu setuju dengan penyataan tersebut. Hal ini mungkin disebabkan pelajar melihat teks KOMSAS Jendela Menghadap Jalan tidak mempunyai perkataan yang tinggi nilainya lalu mereka beranggapan bahasa yang digunakan tidak indah dan menarik. Namun, penggunaan kosa kata yang hebat bukanlah satu-satunya ukuran bagi menentukan aspek bahasa yang indah dan menarik. Buktinya, bilangan majoriti bersetuju dan disokong oleh $24 \%$ yang sangat bersetuju bahawa teks KOMSAS Jendela Menghadap Jalan mempunyai bahasa yang baik dan menarik.

Bukan itu sahaja, teks tersebut juga telah memainkan peranan dalam membantu meningkatkan kemahiran berbahasa dalam kalangan pelajar. Struktur ayat dan penggunaan kosa kata yang digunakan telah membantu memperkayakan kemahiran berbahasa dalam kalangan pelajar. Kemahiran berbahasa ini penting dalam membantu pelajar untuk lebih mahir dari segi pengucapan mahupun penulisan. Lazimnya, seringkali situasi pelajar mempunyai idea-idea yang bernas namun tidak mampu menghurai hujah-hujah mereka dengan baik. Justeru, kemahiran berbahasa penting dalam menjadi pengantara untuk pelajar menghuraikan idea-idea mereka dengan pengolahan yang lebih baik. Lantaran itu, teks KOMSAS antara medium yang mampu menggalakkan peningkatan kemahiran berbahasa dalam kalangan pelajar (Rujuk Jadual 4).

JADUAL 4 Teks KOMSAS mampu meningkatkan kemahiran berbahasa dalam kalangan pelajar

\begin{tabular}{|l|c|c|}
\hline \multicolumn{1}{|c|}{ Pemeringkatan } & Kekerapan & Peratus (\%) \\
\hline Sangat Tidak Setuju & 3 & 2 \\
\hline Tidak Setuju & 31 & 21 \\
\hline Setuju & 88 & 58 \\
\hline Sangat Setuju & 29 & 19 \\
\hline JUMLAH & 151 & 100 \\
\hline
\end{tabular}

Berdasarkan kaedah borang soal selidik yang telah dijalankan, hasil daripada pembacaan terhadap teks KOMSAS Jendela Menghadap Jalan, kemahiran berbahasa dalam kalangan pelajar semakin bertambah baik dan hal ini sangat dipersetujui oleh 29 orang pelajar yang menjadi responden. Meskipun begitu, terdapat pelajar yang tidak bersetuju dengan kenyataan ini, namun kenyataan ini tetap 
dipersetujui oleh 88 orang pelajar. Kemahiran berbahasa sedia ada yang kurang baik merupakan faktor yang mengakibatkan sejumlah 31 orang pelajar tidak bersetuju disusuli dengan 3 orang pelajar yang sangat tidak bersetuju. Hal ini demikian kerana proses untuk meningkatkan kemahiran berbahasa melalui pembacaan terhadap bahan teks KOMSAS agak sukar jika tidak seiring dengan usaha-usaha untuk meningkatkan kemahiran berbahasa yang lain.

Selain membantu meningkatkan kemahiran berbahasa dalam kalangan pelajar, pengajaran dan pembelajaran menggunakan novel Jendela Menghadap Jalan berjaya merangsang minat pelajar untuk membaca karya-karya sastera yang lain. Perkara ini adalah didorong oleh kesan pembacaan yang diperoleh yang memberikan kepuasan. Selain daripada susunan jalan cerita yang menarik, konteks dan cara kepengarangan yang baik juga menjadikan sesebuah novel itu menjadi tarikan kepada para pelajar. Justeru, apabila pelajar membaca teks novel Jendela Menghadap Jalan, pelajar mula tertarik untuk membaca karya-karya sastera yang lain kerana kepuasan yang dirasai hasil daripada pembacaan terhadap Jendela Menghadap Jalan. Situasi ini benar-benar berlaku dalam kalangan pelajar, iaitu pelajar setuju bahawa proses pembelajaran dan pengajaran teks KOMSAS ini telah mendorong mereka untuk membaca teks karya yang lain seperti yang dapat dilihat dalam Jadual 5 berikut:

JADUAL 5 Teks KOMSAS sebagai dorongan untuk pembacaan karya sastera lain

\begin{tabular}{|l|c|c|}
\hline \multicolumn{1}{|c|}{ Pemeringkatan } & Kekerapan & Peratus (\%) \\
\hline Sangat Tidak Setuju & 9 & 6 \\
\hline Tidak Setuju & 51 & 34 \\
\hline Setuju & 68 & 45 \\
\hline Sangat Setuju & 23 & 15 \\
\hline JUMLAH & 151 & 100.0 \\
\hline
\end{tabular}

Berdasarkan kajian ini, teks KOMSAS dapat dilihat sebagai satu modus operandi yang berjaya dalam usaha menggalakkan pembacaan pelajar terhadap teks karya sastera. Hal ini kerana minat seseorang pelajar dapat dipupuk melalui hasil pembacaannya terhadap bahan bacaan pada peringkat sekolah. Lanjutan itu, pelajar mula terdedah dengan pelbagai teks karya sastera yang menarik minat lantas mendorong pelajar untuk membaca teks tersebut. Hasilnya, seramai 68 orang pelajar bersetuju diikuti dengan 23 orang pelajar yang sangat bersetuju dengan pernyataan ini. Jumlah ini merupakan jumlah majoriti yang secara tidak langsung dapat mengesahkan pernyataan tersebut.

Seterusnya, dari segi konteks novel Jendela Menghadap Jalan, didapati bahawa jika diamati dari awal hingga akhir novel ini mengisahkan tentang watak utama yang terdiri daripada pelajar tingkatan 5 bernama Lili. Pemilihan watak remaja sebagai watak utama secara tidak langsung memudahkan pembaca yang terdiri daripada kalangan remaja mudah untuk menghayati memandangkan situasi demikian dekat dengan diri mereka. Watak remaja, Lili digambarkan sebagai remaja yang memberikan teladan yang baik apabila Lili mengamalkan gaya pemakanan yang sihat. Tambahan lagi, Lili juga mempunyai gemar membaca. Buktinya, semasa perjalanan balik ke kampung datuk dan neneknya, Lili leka membaca buku Panduan Pemakanan Sihat Melalui Sayur-sayuran dan Buahbuahan. Malah, Lili juga digambarkan sebagai watak yang mudah untuk berkawan dengan sesiapa sahaja tanpa mengira warna kulit. Buktinya, Lili berkawan rapat dengan Danel yang merupakan bangsa Cina dan Geetha yang berbangsa India. Bukan itu sahaja, Lili bersama rakan-rakannya itu juga berani bertindak dalam menyelesaikan konflik yang berlaku di kampung tersebut. Konflik yang wujud antara penduduk kampung timbul ekoran daripada isu untuk meletakkan kubah masjid. Wakil Rakyat telah memberi pilihan sama ada ingin membina sebuah dewan masyarakat atau mendirikan sebuah masjid. Walau bagaimanapun, kebanyakan penduduk kampung memilih untuk membina kubah surau berbanding membina sebuah masjid kerana masalah kekurangan tanah. Jika diteliti secara keseluruhan, dapat ditafsirkan bahawa antara ciri-ciri lain bagi sesebuah novel remaja itu dipilih sebagai novel KOMSAS adalah tidak lain dan tidak bukan melalui gambaran bagi setiap watak terutamanya watak 
remaja. Peranan watak yang memberikan motivasi kepada pembaca, lebih-lebih lagi watak remaja unggul, iaitu watak yang mencerminkan nilai-nilai yang positif seperti berani, mudah memaafkan, sedia membantu orang lain dan sebagainya. Kebenaran mengenai perkara ini dapat dilihat melalui Carta 4.

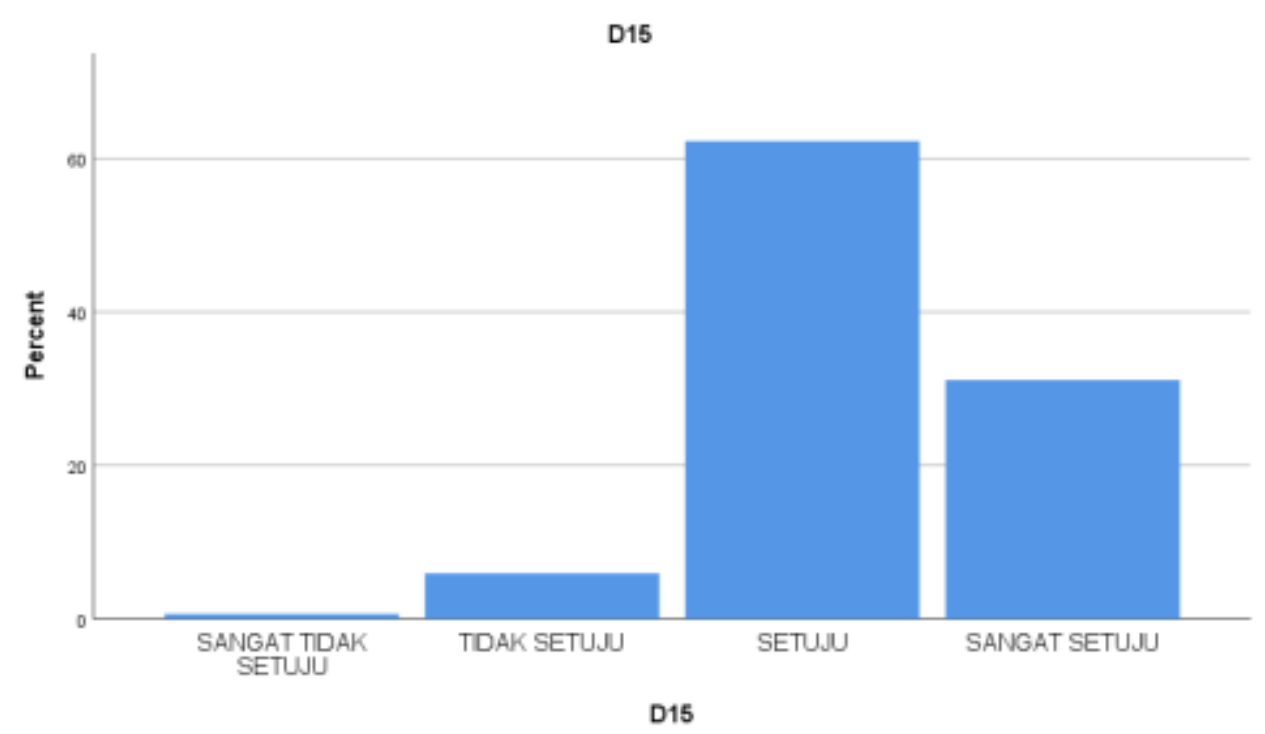

Carta 4 Teks KOMSAS memberikan teladan yang berguna

Berdasarkan kajian soal selidik, 62\% bersetuju bahawa teks KOMSAS Jendela Menghadap Jalan memberikan teladan dan contoh yang baik. Hal ini bermakna, pengarang berjaya menggarap watak remaja unggul sekali gus memberikan motivasi dalam kalangan pelajar. Pengajaran berkaitan nilai-nilai murni sememangnya diberikan perhatian dalam konteks novel sebelum dipilih menjadi bahan KOMSAS. Pendedahan mengenai sifat-sifat mulia seseorang remaja unggul mampu memberikan inspirasi kepada pembentukan diri sahsiah dalam kalangan pelajar. Oleh itu, aspek ini menjadi sebahagian daripada kriteria yang mesti dipenuhi oleh sesebuah novel sebelum layak dijadikan sebagai teks KOMSAS bagi proses pembelajaran dan pengajaran di sekolah.

\section{SAMBUTAN PELAJAR TERHADAP NOVEL JENDELA MENGHADAP JALAN}

Dalam usaha menyemai nilai kesusasteraan dalam diri para pelajar, usaha ini juga berdepan dengan beberapa isu yang perlu diberikan perhatian. Oleh yang demikian, kajian ini juga melihat respons pelajar daripada sudut penerimaan pelajar sama ada positif mahupun negatif. Justeru, permasalahan yang dihadapi oleh pelajar dalam proses pembelajaran dan pengajaran KOMSAS diambil kira dalam kajian ini. Responden seramai 151 mempunyai tahap pemikiran dan kefahaman serta pendapat yang berbezabeza. Justeru, meskipun secara keseluruhan dapat dilihat bahawa rata-rata responden memberikan respon yang baik terhadap teks KOMSAS Jendela Menghadap Jalan, namun masih terdapat segelintir responden daripada kalangan pelajar yang agak kurang menyambut baik teks ini. Hal ini adalah tidak lain dan tidak bukan kerana minat membaca dalam kalangan pelajar itu sendiri. Tidak semua pelajar yang gemar membaca tidak kira sama ada pelajar tersebut berlatar belakangkan aliran sains mahupun aliran sastera. Buktinya, masih terdapat pelajar yang tidak berminat untuk membaca terutamanya bahan bacaan peringkat sekolah. Isu ini secara tidak langsung menjadikan pelajar kurang berminat dengan teks KOMSAS sekaligus tidak menerima teks Jendela Menghadap Jalan dengan baik. Hal ini dapat dilihat menerusi peratusan berdasarkan borang soal selidik yang diedarkan (Rujuk Carta 5). 


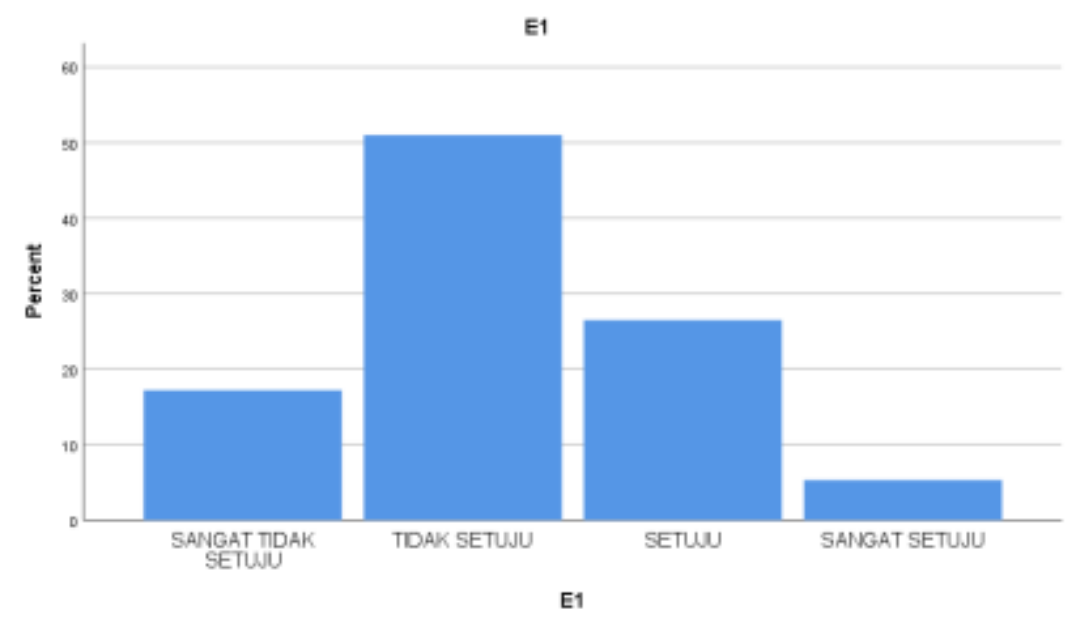

Carta 5 Tahap minat pelajar untuk membaca novel remaja

Hasil daripada soal selidik mendapati bahawa $51 \%$ peratus responden tidak bersetuju dengan pernyataan kurang berminat membaca novel remaja terutama yang terdapat dalam KOMSAS. Peratusan ini agak tinggi dan membimbangkan. Justeru, guru memainkan peranan paling penting dalam membantu pelajar yang kurang berminat membaca novel remaja lebih-lebih lagi berkaitan dengan teks KOMSAS. Guru perlu mempelbagai inisiatif bagi memupuk minat membaca dalam kalangan pelajar. Antara usaha yang boleh dilakukan ialah menggunakan alat bantu mengajar bagi mewujudkan suasana yang menarik semasa proses pembelajaran dan pengajaran berlangsung. Hal ini secara tidak langsung merangsang pelajar untuk membaca teks KOMSAS untuk membolehkan dirinya turut serta dalam sesi pembelajaran dan pengajaran yang menyeronokkan.

Begitu juga dengan isu bahasa yang dikemukakan oleh pelajar. Secara umumnya, sastera sememangnya tidak dapat lari dengan struktur ayat yang panjang dan meleret-leret dan apabila bahasa yang digunakan pula agak sukar untuk difahami, maka pelajar menghadapi kesukaran untuk memahami serta menghayati teks KOMSAS tersebut. Secara keseluruhannya, novel remaja Jendela Menghadap Jalan menggunakan bahasa yang agak mudah untuk difahami bagi tahap pembacaan pelajar sekolah menengah. Namun, terdapat pelajar yang berpendapat bahawa teks KOMSAS ini sukar difahami. Hal ini berkemungkinan daripada struktur ayat yang memerlukan pelajar untuk mendalami bagi merasai jalan cerita yang sebenar mengikut suasana aturan cerita yang hendak disampaikan oleh pengarang. Peratusan ini dapat dilihat seperti dalam Jadual 6 dan Jadual 7.

JADUAL 6 Kesukaran memahami teks KOMSAS disebabkan gaya bahasa yang digunakan.

\begin{tabular}{|l|c|c|}
\hline \multicolumn{1}{|c|}{ Pemeringkatan } & Kekerapan & Peratus (\%) \\
\hline Sangat Tidak Setuju & 21 & 14 \\
\hline Tidak Setuju & 78 & 52 \\
\hline Setuju & 39 & 26 \\
\hline Sangat Setuju & 13 & 8 \\
\hline JUMLAH & 151 & 100 \\
\hline
\end{tabular}

JADUAL 7 Keperluan untuk mengulang-baca bagi memahami cerita dalam teks KOMSAS

\begin{tabular}{|l|c|c|}
\hline \multicolumn{1}{|c|}{ Pemeringkatan } & Kekerapan & Peratus (\%) \\
\hline Sangat Tidak Setuju & 16 & 11 \\
\hline Tidak Setuju & 57 & 38 \\
\hline Setuju & 45 & 30 \\
\hline Sangat Setuju & 33 & 21 \\
\hline JUMLAH & 151 & 100 \\
\hline
\end{tabular}


Rentetan daripada bahasa dalam novel remaja Jendela Menghadap Jalan yang sukar difahami, pelajar juga terpaksa membaca teks KOMSAS tersebut berulang kali. Hal ini dapat dilihat melalui jumlah peratusan sebanyak $30 \%$ yang bersetuju dan $21 \%$ yang sangat bersetuju dengan pernyataan ini. Hal ini membawa kepada jumlah 78 orang pelajar yang terpaksa membaca teks KOMSAS berulang kali untuk memahami jalan cerita teks. Hal ini didorong oleh beberapa faktor seperti bahasa yang sukar difahami, struktur ayat yang meleret dan mungkin juga disebabkan oleh isu yang terlalu banyak hendak disampaikan kepada pembaca. Justeru, pelajar membaca berulang kali untuk lebih faham mengenai isu yang hendak diutarakan.

Secara keseluruhannya, teks KOMSAS Jendela Menghadap Jalan memperlihat ciri-ciri novel remaja yang layak untuk dijadikan sebagai bahan bacaan teks KOMSAS di peringkat sekolah. Ciri-ciri yang dimaksudkan ialah ciri-ciri yang mengangkat watak remaja sebagai watak utama yang dicorakkan berdasarkan sifat-sifat seorang remaja unggul. Ciri-ciri remaja unggul disifatkan sebagai remaja yang mempunyai nilai-nilai murni yang baik. Malah, novel remaja yang dipilih menjadi teks KOMSAS juga lazimnya mempunyai nilai-nilai kemanusiaan dan jati diri individu bagi meningkatkan motivasi dalam kalangan pelajar. Bukan itu sahaja, mesej pengajaran yang hendak disampaikan itu juga bertujuan untuk menyuntik peribadi yang mulia sekaligus mendorong kepada pembentukan akhlak yang teguh dalam kalangan pelajar khususnya. Sehubungan dengan itu, masalah-masalah yang dihadapi oleh pelajar dalam proses pembelajaran teks hendaklah diberikan perhatian agar tiada pelajar yang tercicir daripada manfaat tujuan sastera itu diperkenalkan. Secara tidak langsung, perkara ini memperlihatkan sambutan secara keseluruhan terhadap teks KOMSAS ini menjurus ke arah yang positif. Pelajar memberikan respon yang amat baik dari segi aspek kandungan teks KOMSAS bagi proses pembelajaran dan pengajaran yang diadakan di sekolah.

\section{KESIMPULAN}

Berdasarkan analisis yang telah dibuat sepanjang Kajian Resepsi Pembaca Impak Pemenang Novel Remaja Hadiah Sastera Kumpulan Utusan (HSKU) terhadap Pelajar, didapati bahawa hala tuju sesebuah novel remaja yang memenangi HSKU adalah menjadi teks KOMSAS pada peringkat sekolah selain daripada menjadi bahan bacaan bagi umum. Novel remaja yang memenangi HSKU memberi kelebihan kepada novel itu sendiri semasa proses menentukan novel tersebut layak mahupun tidak layak untuk diangkat menjadi teks KOMSAS. Hal ini kerana sebelum terpilih menjadi teks KOMSAS peringkat sekolah, beberapa kriteria mesti dipenuhi oleh sesebuah novel remaja. Hal ini dapat dijelaskan menerusi teks KOMSAS Jendela Menghadap Jalan yang merupakan teks KOMSAS TINGKATAN empat di zon 1. Jendela Menghadap Jalan memperlihatkan kriteria seperti mengandungi aspek bahasa yang mampu membantu bagi membina kemahiran berbahasa dalam kalangan pelajar. Selain daripada mempunyai kandungan mesej yang menarik dan memberikan pengajaran, Jendela Menghadap Jalan juga menonjolkan ciri-ciri remaja unggul yang memperlihatkan watak remaja iaitu Lili sebagai watak yang menerajui jalan cerita dengan sifat-sifat keberanian, bertanggungjawab, berhati mulia, dan berbudi bahasa. Sifat-sifat yang berunsurkan nilai murni begitu menyerlah dalam teks KOMSAS dengan harapan dapat menyuntik motivasi dalam kalangan pelajar.

Sehubungan dengan itu, terdapat beberapa cadangan dan ulasan yang diperoleh hasil daripada temu bual bersama para guru. Hasil daripada pemerhatian guru mendapati bahawa kebanyakan novel yang dipilih menjadi teks KOMSAS hanya mengangkat watak remaja perempuan sebagai watak utama. Sementara watak remaja lelaki hanya sebagai watak sampingan yang mendukung peranan watak utama. Malah lebih teruk apabila berkaitan masalah sosial, pasti akan dikaitkan dengan remaja lelaki. Masalah seperti ponteng sekolah, menghisap rokok dan sebagainya. Perkara ini seolah-olah menjadi trend yang mengakibatkan motivasi dalam kalangan pelajar lelaki itu sendiri kurang, tidak seperti remaja perempuan. Hal ini berlaku dalam teks Jendela Menghadap Jalan. Di samping itu, Jendela Menghadap Jalan juga memaparkan terlalu banyak isu yang ingin diutarakan sehinggakan terdapat isu yang tidak memberikan motivasi dalam ruang lingkup seorang pelajar. Malah isu yang memperlihatkan watak utama menyelesaikan konflik orang dewasa dilihat sebagai satu isu yang tidak rasional dan kurang sesuai. Isu yang terlalu banyak juga mengakibatkan teks KOMSAS menjadi meleret menyebabkan guru 
sukar untuk mengajar kerana pelajar kurang minat untuk membaca teks yang tebal dan meleret berbanding dengan teks tingkatan 5 mereka, iaitu Songket Benang Emas yang lebih diminati pelajar.

Justeru, antara penambahbaikan yang boleh dilakukan adalah penelitian diberikan kepada jalan cerita sesebuah teks KOMSAS yang patut memberi keutamaan kepada peningkatan motivasi dalam kalangan pelajar tanpa mengira jantina. Malah, penetapan kepada satu isu utama yang ingin diketengahkan amat penting supaya pelajar tidak terkeliru untuk memberikan pandangan mereka tersendiri mengenai tema yang menjadi pokok utama bagi sesebuah novel. Di samping itu, hal ini juga dapat memudahkan para guru untuk menjalankan proses pembelajaran dan pengajaran dengan adanya satu matlamat utama yang hendak dicapai hasil daripada pembacaan terhadap teks KOMSAS tersebut. Penggunaan struktur ayat yang ringkas dan padat juga penting dalam memastikan pelajar tidak terbeban sekaligus mengelakkan pelajar bosan dan tidak berminat untuk membaca. Dalam konteks yang lebih luas, proses pemilihan teks KOMSAS hendaklah seiring dengan matlamatnya untuk memupuk kesusasteraan dalam diri setiap pelajar.

\section{RUJUKAN}

Izzah Abdul Aziz. (2000). Inovasi pengajaran kesusasteraan. Kertas kerja yang dibentangkan dalam Seminar Kebangsaan Teks Komponen Kesusasteraan Melayu dalam Mata Pelajaran Bahasa Melayu, Kuala Lumpur, 12-14 Julai 2000. Kementerian Pendidikan Malaysia (1999).

Marohaini Yusof. (2001). Landasan pengajaran komponen sastera dalam bahasa Melayu. Jurnal Dewan Bahasa, 1(6), 20-26.

Chew Fong Peng. (2009). Pendidikan Sastera Perpaduan Menerusi KOMSAS Tingkatan 4:

Pelaksanaan dan Kesannya. Jurnal Pendidikan Malaysia 34(2):15 - 31.

Lin Tian Wong \& Masnida Md Khambari. (2017). Kaedah Pemilihan Media Pengajaran Komponen Sastera (KOMSAS) oleh Guru Cemerlang Bahasa Melayu. International Journal of Educating and Training (injET)3 (2) November:1-11.

Ruhaini Matdarin. (2014). Jendela Menghadap Jalan. Kuala Lumpur: Utusan Publication \& Distributors Sdn. Bhd.

Sohaimi Abdul Aziz. Teori Kritikan Sastera. (2005). Dewan Bahasa dan Pustaka: Kuala Lumpur.

Umar Junus. (1985). Resepsi Sastra: Sebuah Pengantar. Penerbit PT Gramedia: Jakarta.

Shamsudin Othman, Ghazali Lateh, \& Nurul Faidzah Ab. Hadi (2014). Penggunaan Gaya Bahasa Sastera Dalam Pengajaran Bahasa Melayu Di Sekolah Menengah. Jurnal Pendidikan Bahasa Melayu, Vol. 4, Bil. 1 (Mei 2014): 59-64.

Shamsudin Othman dan Abdul Rasid Jamian (2013). Pelaksanaan Elemen Sastera Dalam Pengajaran dan Pembelajaran Seni Bahasa Kurikulum Standard Sekolah Rendah, Jurnal Bahasa, 13 (2).

Norhidayu Binti Kassim. (2011). Persepsi Kanak-Kanak Terhadap Watak dan Perwatakan Tokoh Dalam Karya Sastera Kanak-Kanak Berunsur Sejarah. Tesis sarjana yang tidak diterbitkan, Universiti Putra Malaysia.

Norul Haida Bt. Hj. Reduzan, Robe'ah Yusuf dan Hidayah Bt. Hashim. (2016). Aplikasi Model VAK Dalam Gaya Pengajaran Dan Pembelajaran Komsas Bahasa Melayu, E-Proceeding of The Regional Conference On Civilization and Islamic Thoughts (ReCIT) Malays Diaspora: Developments and Challenges. Masjid Ibrahim, Perth, Australia.

Sahlan Mohd. Saman. (2001). Teori Resepsi. Bengkel Ikhtisar Teori Sastera Kedua anjuran Bahagian Teori dan Kritikan Sastera, Jabatan Sastera. Kuala Lumpur.

Ariff Bin Mohammad. (2009). Analisis Kesesuaian Pemilihan Teks Bagi Genre Cerpen dan Novel Komponen Sastera Dalam Pendidikan Bahasa Melayu, Universiti Pendidikan Sultan Idris. Dicapai pada 16 November 2017, daripada http://pustaka2.upsi.edu.my/eprints/433/1/.

Asia Padmopuspito. (1993). Teori Resepsi dan Penerapannya. Dicapai pada 5 Oktober 2017, daripada https://www.academia.edu/8916770/teori_resepsi_dan_penerapannya

Faziela Abu Bakar, Nik Rafidah Nik Muhammad Affendi. (2015). Unsur Emosi dalam Novel Komsas. Universiti Putra Malaysia. Dicapai pada 22 Januari 2018, daripada http://www.myjurnal.my/public/articleview.php?id=93004

Kementerian Pendidikan Malaysia. Dasar Kurikulum Kebangsaan. Dicapai pada 28 Januari 2018, daripada https://moe.gov.my/index.php/my/dasar/kurikulum-kebangsaan 